\title{
Characteristics, Fertility Status and Fertility Capability Classification of Steep Slope Soils of the Dschang Cliff (Cameroon Western Highlands)
}

\author{
Evariste Desire Moundjeu1 ${ }^{*}$, Emile Temgoua1, Primus Azinwi Tamfuh ${ }^{1,2}$, Joseph Guepi Vounang1, \\ Jean-Paul Youssie Kabiwa1, Armand Sylvain Ludovic Wouatong1, Dieudonné Bitom ${ }^{1}$
}

${ }^{1}$ Department of Soil Science, Faculty of Agronomy and Agricultural Sciences, University of Dschang, Dschang, Cameroon

${ }^{2}$ Department of Mining and Mineral Engineering, National Higher Polytechnic Institute, University of Bamenda, Bamenda, Cameroon

Email: *evadesire2006@yahoo.fr

\begin{abstract}
How to cite this paper: Moundjeu, E. D., Temgoua, E., Tamfuh, P. A., Vounang, J. G., Kabiwa, J.-P. Y., Wouatong, A. S. L., \& Bitom, D. (2021). Characteristics, Fertility Status and Fertility Capability Classification of Steep Slope Soils of the Dschang Cliff (Cameroon Western Highlands). Journal of Geoscience and Environment Protection, 9, 164-179.
\end{abstract}

https://doi.org/10.4236/gep.2021.97011

Received: June 7, 2021

Accepted: July 25, 2021

Published: July 28, 2021

\section{Copyright $\odot 2021$ by author(s) and} Scientific Research Publishing Inc. This work is licensed under the Creative Commons Attribution International License (CC BY 4.0).

http://creativecommons.org/licenses/by/4.0/

\begin{abstract}
Mountainous ecosystem soils are subject to colonization nowadays for agricultural purposes due to an increasing population in towns making the detailed characterization of such soils indispensable. This work aims to characterize the steep slopes soils of the Dschang hills and to evaluate their fertility level for agricultural valorization. Thus, four soil profiles were dug at various topographic positions (summit (SP), shoulder (MP), backslope (BP) and footslope (PP)) following a toposequence. Samples of disturbed and undisturbed soils were taken and analyzed in the laboratory according to standard methods. The Fertility Capability Classification (FCC) and simple limitation methods were used to identify major agricultural constraints. The main results show that profiles thickness is moderate, between 0 and $120 \mathrm{~cm}$, with a high sand content (at least 50\%) over the entire toposequence, especially at the surface. The study site has four types of soils, namely Eutric Cambisols (ochric) in SP and Leptic Eutric Cambisols (Humic) in MP, Eutric Cambisols (Humic) in BP and Stagnic Oxygleyic Dystric Gleysols (Humic) in pp. The soils are very acidic at PP, moderately acidic at BP and SP and slightly acidic at MP. Organic matter is higher at the surface than at depth at the topographic segments of MP, BP and PP and low to SP. The $\mathrm{C} / \mathrm{N}$ ratio is high $(>17)$ in all profiles except $\mathrm{P} 4$ $(<10)$. In addition, the cation exchange capacity (CEC), the sum of exchangeable bases, total nitrogen and available phosphorus is low in all profiles. The $\mathrm{Ca} /$ $\mathrm{Mg} / \mathrm{K}$ balance in all the profiles shows a cation imbalance and a relatively high concentration of exchangeable potassium compared to the ideal situation
\end{abstract}


(76\% Ca, $18 \% \mathrm{Mg}$ and $6 \% \mathrm{~K}$ ). The major constraints to crop production are: aluminum toxicity (a) and nutrients leaching (e), textural discontinuity (LS), flooding (g), low nutrient reserve $(\mathrm{k})$, sand $(\mathrm{S})$, clay $(\mathrm{C})$ and slope $(\mathrm{t})$. Hence the fertility capacity classes of these soils are CCaegk (PP), SSek (BP), SSte (MP) and LSaek (SP). To improve the yield, it will require off-season crop cultivation, fertilization and liming, and earthworks.

\section{Keywords}

Steep Slope Soils, Fertility Capability Classification, Nutrient Balance, Cameroon Western Highlands

\section{Introduction}

Population growth has generated an increase in food demand which can only be satisfied by an intensification of agriculture (FAO, 2006). Sub-Saharan Africa must increase its agricultural production by $4 \%$ each year to meet this demand (Griffon \& Marty, 1993). The existence of large areas of "underutilized" land would meet this challenge (FAO, 2006). The 2009 Growth and Employment Strategy Paper (DSCE) sets Cameroon's objectives to increase, on the one hand, agricultural yields, and on the other hand, to increase agricultural areas in the order of $30 \%$ compared to the 2005 level (DSCE, 2009). To meet this demand, all agricultural land in Cameroon and particularly those on steep slopes needs to be valorized. Such soils on steep slopes are quite common in mountainous areas. The major characteristics of soils in such landscaped are their thin profiles, high leaching potential and continuous rejuvenation due to erosion induced by steep slope (Bucrep, 2010). Due to demographic pressure, the colonization and development of soils in areas with steep slopes previously reserved for grazing and market gardening has become a necessity and often leads to farmer-grazer conflicts. This is the case of the Dschang hills in the Menoua Division of Cameroon, which often present very rugged landscapes with steep slopes and an escarpment of more than $700 \mathrm{~m}$ in altitude (Fotsing, 1999). The agricultural development of these lands requires detailed knowledge of morphological, physical and chemical properties of the soils. With the aim of enhancing the value of these marginal lands, this study was devoted to a morphological, physical and chemical characterization followed by an assessment of soil fertility in Dschang cliff. The results obtained will provide data to farmers on the management strategies to be adopted on such soils for optimum soil productivity.

\section{Material and Methods}

\subsection{Study Zone}

The work was carried out in Nteingue locality in Dschang, more commonly called the "Dschang Cliff", characterized by spectacular escarpment. It stretches 
over $12 \mathrm{~km}$ and culminates at about $1450 \mathrm{~m}$ altitude, between the coordinates $10^{\circ} 30^{\prime} 00^{\prime \prime} \mathrm{E}$ and $5^{\circ} 21^{\prime} 00^{\prime \prime} \mathrm{N}$, in the Cameroon Western Highlands (Figure 1). The cliff is subject to a humid tropical climate and characterized by two seasons: a rainy season between mid-March and mid-November, and a dry season running from mid-November to mid-February. The mean annual temperature is $15^{\circ} \mathrm{C}$ and the total annual precipitation is $1908 \mathrm{~mm}$ (Climate-Data.org, 2019). The vegetation is herbaceous savannah and fringes of a strongly degraded forest. The study area has a drainage network that belongs to the Menoua watershed, the main tributary of the Nkam. The soils in the study area are Cambisols on the slopes, midslope and summit of mountains and Gleysols in the valleys. The main geological formations of the area are granite and gneiss. The main activities of the inhabitants are agriculture.

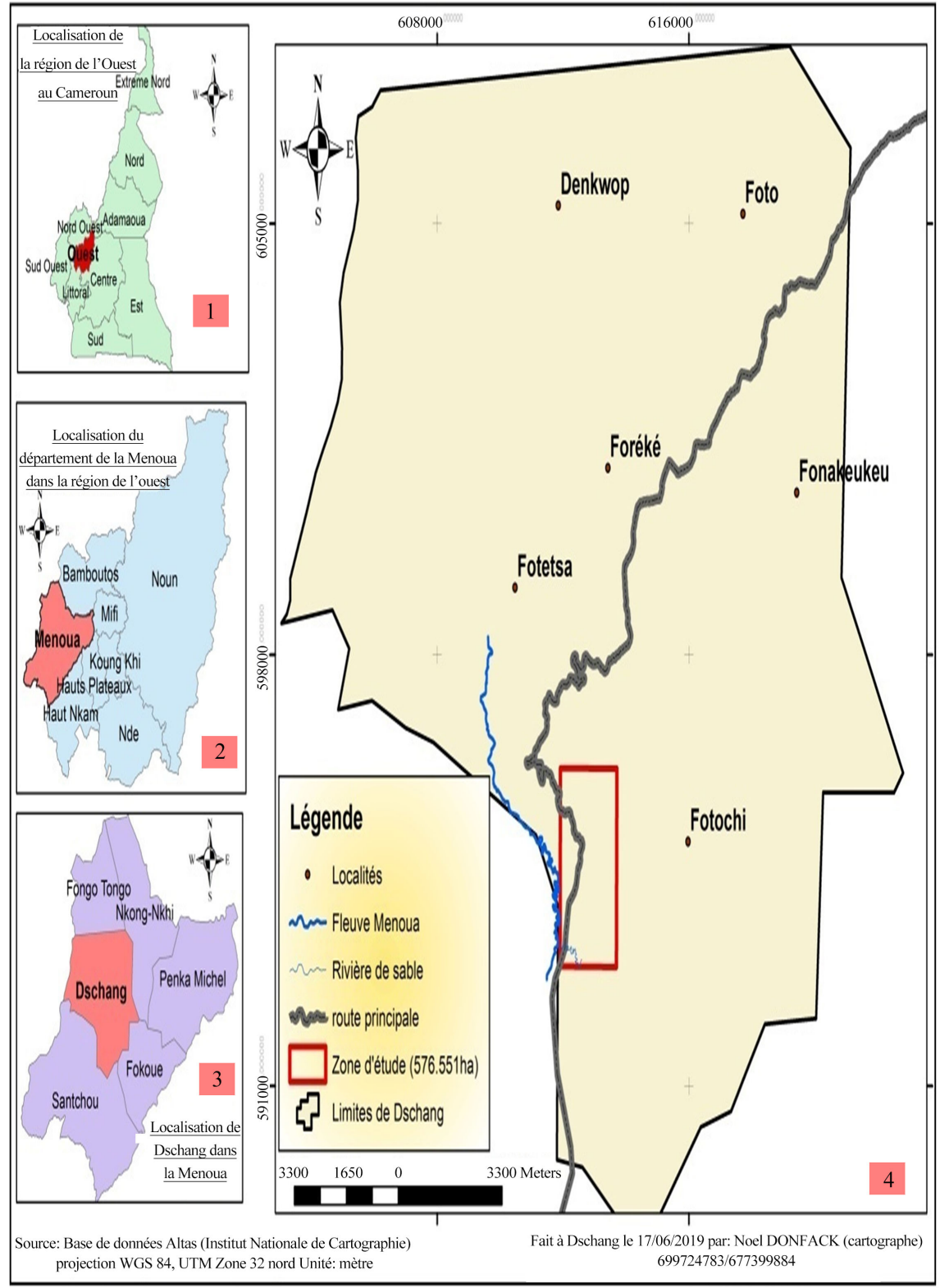




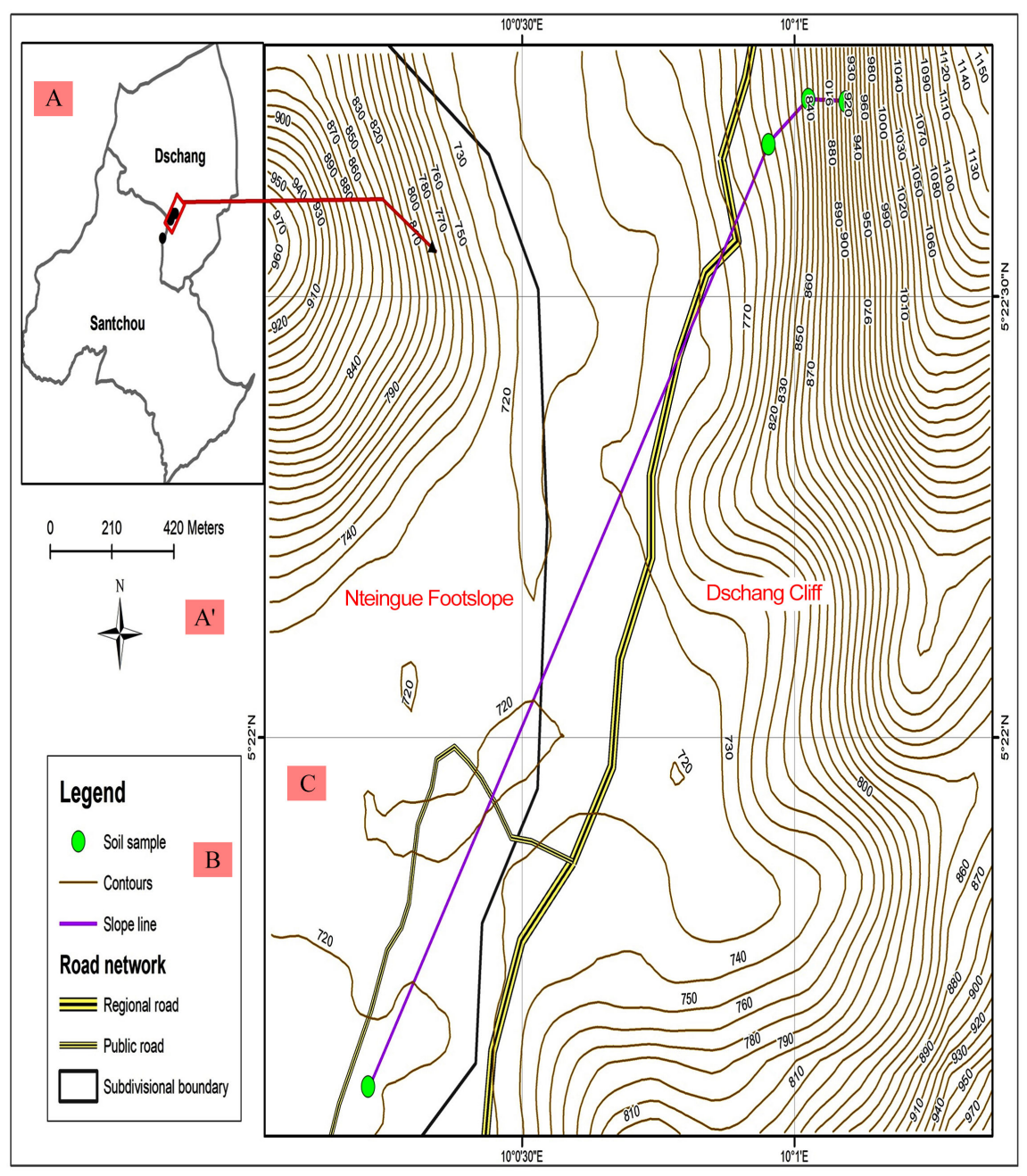

Figure 1. map of Cameroon (1) showing the menoua department in the West Cameroon region (2), Dschang district (3), the location of the study area (4 and A) in Dschang sub division and $(\mathrm{C})$ is soil profiles in Dschang cliff.

\subsection{Methodology}

\subsubsection{Morphological Characterization}

A toposequence was selected along a North-South transect based on its easy accessibility. The identification of four open soil profiles was based on auger boreholes initially allowing rapid observation of the soil on the site, thus allowing the limitation of the most homogeneous soil units possible. They also made it possible to identify the points for the realization of representative soil profiles for a more detailed study of soil distribution and vertical soil variability. The soil pits are $500 \mathrm{~m}$ apart and have a maximum depth of $1.5 \mathrm{~m}$. Each profile was identified by its topographic position (summit (SP), shoulder (MP), backslope (BP) and footslope (PP)) following the model described above. The scientific classification is that of the World Reference Base for Boil Resources (WRB, 2014).

\subsubsection{Soil Sampling}

At the level of each profile, the sample was taken horizon by horizon from left to 
right to make a composite of 1000 grams and from bottom to top using the knife and a spade for analysis. Concerning the determination of the bulk density, the undisturbed samples were taken horizon by horizon from bottom to top using cylindrical rings of $100 \mathrm{~cm}^{3}$. These cylindrical rings were well preserved in plastic bags for drying at $105^{\circ} \mathrm{C}$ in the laboratory. Disturbed samples from each horizon were dried at room temperature, in the laboratory $\left(25^{\circ} \mathrm{C}-30^{\circ} \mathrm{C}\right)$, prior to separation of coarse elements from fine earth, using a $2 \mathrm{~mm}$ square mesh sieve. The fine soil samples were packaged in plastic bags and sent to the soil analysis and environmental chemistry research unit of the University of Dschang Cameroon, for physical and chemical analyzes.

\subsubsection{Soil Analysis in the Laboratory}

The physico-chemical analyses were carried out at the Research Unit of Soil Analysis and Environmental Chemistry (URASCE) of the University of Dschang (Cameroon). The soil moisture was obtained after weighing and oven-drying a soil sample at $105^{\circ} \mathrm{C}$ for 24 hours. The particle density (Dr) was obtained by the pycnometer method. The bulk density $(\mathrm{Da})$ was obtained by getting the ratio of oven-dry mass at $105^{\circ} \mathrm{C}$ to the total volume of the known soil (Pauwels et al., 1992). The porosity was also obtained as the ratio between the bulk density (Da) and the particle density (Dr). The particle size distribution analysis of the soils was carried out by the Robinson pipette method (Pauwels et al., 1992). The classification of soil texture was done according to the USDA texture triangle (Omoko, 1996). The $\mathrm{pH}-\mathrm{H}_{2} \mathrm{O}$ was determined in a soil/water ratio of $1: 2.5$ and $\mathrm{pH}-\mathrm{KCl}$ was dosed in a soil/ $\mathrm{KCl}$ mixture of 1:2.5 (Pauwels et al., 1992). The organic carbon (CO) was determined by the Walkley and Black method (Pauwels et al., 1992). The total nitrogen (NT) was determined by the Kjeldahl method (Pauwels et al., 1992). The exchangeable bases were measured by the Metson method (Pauwels et al., 1992). The CEC was measured following the exchangeable bases after the alcohol rinse and introduction of $1 \mathrm{~N} \mathrm{KCl}$ solution. Aluminum was determined by the buffered ammonium acetate extraction method (Ancelin \& Duranel, 2007). Aluminum toxicity (Al) was defined by the Kamprath Equation (1) (Boyer, 1970).

$$
m=\frac{\mathrm{Al} \times 100}{\mathrm{Al}+\mathrm{S}}
$$

The structural stability index (SI) was estimated according to Equation (2) (Ancelin \& Duranel, 2007).

$$
\mathrm{SI}=\frac{1.724 \times \% \text { CO }}{\% \text { silt }+\% \text { clay }} \times 100
$$

where $\mathrm{CO}$ is the organic carbon contained in the soil.

The slaking index (Is) was obtained using equation (Ancelin \& Duranel, 2007).

$$
\text { Is }=\frac{(1.5 \times \% \text { siltfin })+(0.75 \times \text { coarsesilt })}{\% \text { clay }+10 \times \% \mathrm{MO}}-0.2(\mathrm{pH}-7)
$$

The soil organic carbon stock was calculated by Equation (4) (Azinwi et al., 
2020).

$$
\text { SOCS }=\mathrm{Da} \times 10 \times(1-\mathrm{EG}) \times \mathrm{TPC} \times \mathrm{Eh}
$$

SOCS in $\mathrm{t} / \mathrm{ha} ; \mathrm{Da}=$ bulk density in $\mathrm{g} / \mathrm{dm}^{3} ; \mathrm{EG}=$ percentage of coarse elements $\mathrm{TPC}=$ weightcontent of organic carbon in $\mathrm{g} / \mathrm{kg}$; Eh $=$ thickness of the horizon in m.

The fertility index (FI) is obtained by Equation (5) (Azinwi et al., 2020).

$$
\mathrm{FI}=\mathrm{P}+\mathrm{Da}+\mathrm{CEC}+\mathrm{pHwater}+\mathrm{MO}+\mathrm{NT}+\mathrm{P} 0+\Delta \mathrm{pH}+\mathrm{S}
$$

where $\mathrm{P}=$ the available phosphorus, $\mathrm{Da}=$ bulk density, $\mathrm{NT}=$ total nitrogen, $\Delta \mathrm{pH}=$ exchangeable acidity, $\mathrm{S}=$ sum of the exchangeable bases.

The soil requirements for exchangeable bases were determined according to (Azinwi et al., 2020). The soil fertility limitations and fertility capability classification (FCC) units were obtained using FCC version 4 (Euroconsult, 1989). The limiting factors of crop growth were deduced by the simple parametric method (Sys et al., 1991).

\section{Results}

\subsection{Morphological and Physical Characteristics of Soils along the Slope}

Profile P1 is located at the footslope position. It is a shallow soil with two horizons $\mathrm{Ag}$ and $\mathrm{Bg}$. The Ag horizon $(0-10 \mathrm{~cm})$ is black $(7.5 \mathrm{YR} 2 / 0)$ which is sandy clay loam, a granular and plastic structure with many roots and the transition is gradual with the $\mathrm{Bg}$ horizon $(10-120 \mathrm{~cm})$ The $\mathrm{Bg}$ horizon is massive, plastic, dark brown $(7.5 \mathrm{YR} 3 / 4)$ clay with few roots. It is limited at the base by the water (Table 1). It is classified as Stagnic Oxygleyic Dystric Gleysols (Humic) (Figure 2(a) and Figure 2(b)).

\begin{tabular}{|c|c|c|c|c|}
\hline Site characteristics & Summit & Shoulder & Backslope & Footslope \\
\hline \multirow{2}{*}{ Geographic Coordinates } & $612,814.5$ & $612,688.1$ & $612,553.3$ & $611,199.4$ \\
\hline & $594,617.3$ & $594,621.9$ & $594,527.4$ & $592,557.6$ \\
\hline Altitude (m) & 1260.586 & 1085.7841 & 883.2872 & 730.1763 \\
\hline Slope (degree) & $29.98-64.32$ & $15.65-24.97$ & $7.07-15.64$ & $0-7.06$ \\
\hline Vegetation & Grassed Savannah & Grassed Savannah & Grassed Savannah & Grassed Savannah \\
\hline Parent rock & Granite et Gneiss & Granite et Gneiss & Granite et Gneiss & Granite colluvial diposits \\
\hline Soil type & $\begin{array}{l}\text { Eutriccambisols } \\
\text { (ochnic) }\end{array}$ & $\begin{array}{l}\text { lepticEutriccambisols } \\
\text { (humic) }\end{array}$ & $\begin{array}{l}\text { Eutriccambisols } \\
\text { (Humic) }\end{array}$ & $\begin{array}{l}\text { Stagmicoxygleyicdystric } \\
\text { gleysols (humic) }\end{array}$ \\
\hline Soil use & Subsistapencefarming & Subsistencefarming & subsistencefarming & Marketgardeming \\
\hline Human influence & road constructions & $\begin{array}{l}\text { road construction } \\
\text { and housing }\end{array}$ & $\begin{array}{l}\text { road construction } \\
\text { and housing }\end{array}$ & $\begin{array}{l}\text { road construction } \\
\text { and housing }\end{array}$ \\
\hline Mean annual precipitation (mm) & 2352.52 & 2352.52 & 2352.52 & 2872 \\
\hline Mean annual temperature $\left({ }^{\circ} \mathrm{C}\right)$ & 22.57 & 22.57 & 22.57 & 22.68 \\
\hline
\end{tabular}

Table 1. Characteristics of the studied site. 


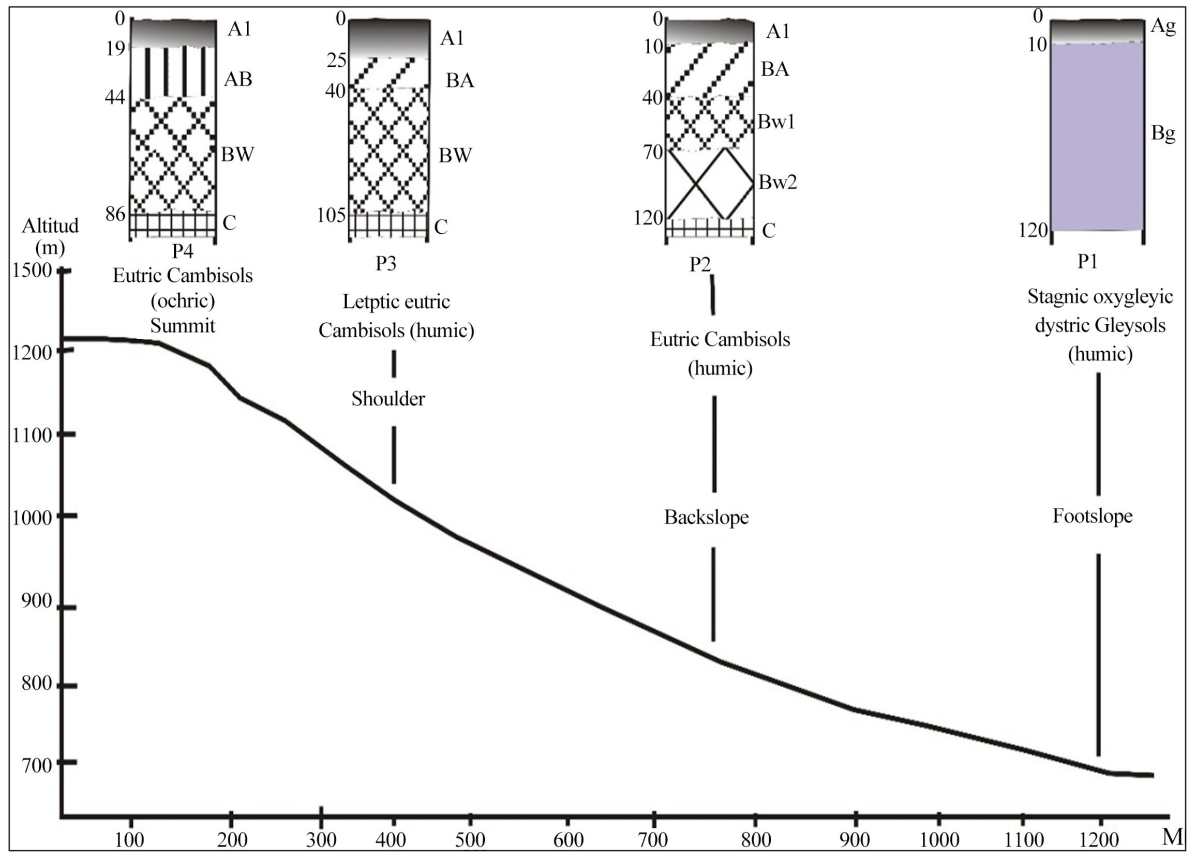

(a)

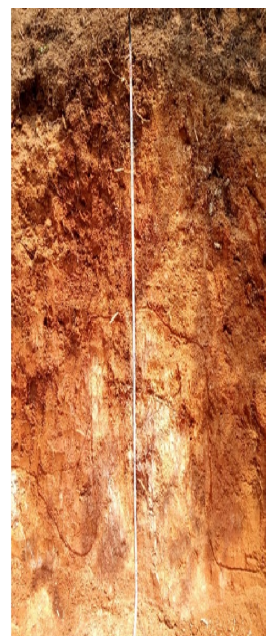

P4 Eutric Cambisols (Ochric) P3 Leptic Eutric Cambisols (Humic)

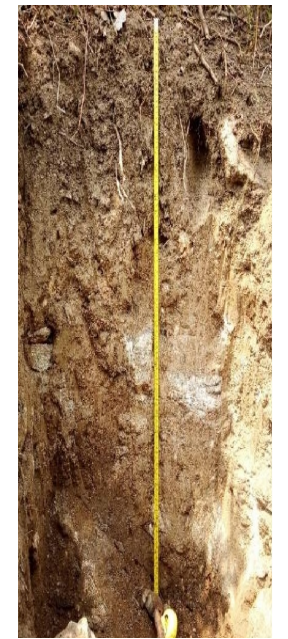

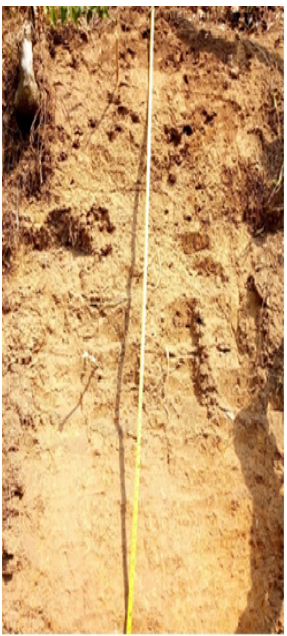

P2 Eutric Cambisols (Humic)

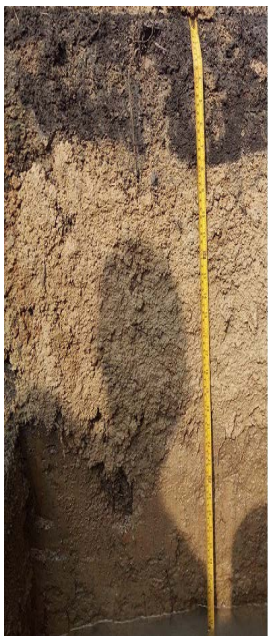

P1 Stagnic Oxygleyic Dystric Gleysols ( Humic)

(b)

Figure 2. (a) Location of the different soil profiles along the toposequence; (b) Photos of the differents soil profiles along the toposequence.

Profile P2 is located at the backslope position. It shows four horizons A1, BA, Bw1, Bw2 and C. The horizon A1 $(0-10 \mathrm{~cm})$ is reddish black brown $(5 \mathrm{YR} 4 / 2)$ lumpy and loose with the presence of several roots, the boundary is clear and sharp. The transitional BA horizon $(10-40 \mathrm{~cm})$ is dark greyish brown $(10 \mathrm{YR} 4 / 2)$, sub-angular blocky, not very compact, porous and the presence of some roots. Bw1 $(40-70 \mathrm{~cm})$ is black brown 10YR4/3 sub-angular blocky and moderately compact, porous and has several roots. Bw2 $(70-120 \mathrm{~cm})$ is yellowish brown with a moderately compact, porous sub-angular blocky structure with few roots. $\mathrm{Cr}$ is greater than $120 \mathrm{~cm}$. It is classified as Eutric Cambisols (Humic). 
Profile P3 is located in the shoulder slope. It shows three horizons A1, BA, Bw and $\mathrm{Cr}$. The A horizon $(0-25 \mathrm{~cm})$ is dark gray with the lumpy and loose structure, porous with numerous roots with a sharp and even transition to the BA horizon $(25-40 \mathrm{~cm})$. The BA is a yellowish brown horizon with a sub-angular blocky structure and moderately compact, moderately porous and with abundant roots. The $\mathrm{Bw}$ horizon $(40-105 \mathrm{~cm})$ is dark gray with a blocky structure and moderate compacity, abundant rock fragments and pebbles, very lightly porous with very few roots $\mathrm{Cr}$ is more than $105 \mathrm{~cm}$ thick. It is classified as Leptic Eutric Cambisols (Humic).

Profile $\mathrm{P} 4$ is located at the summit position. It shows four horizons: $\mathrm{A}, \mathrm{AB}, \mathrm{Bw}$ and $\mathrm{Cr}$. The A horizon $(0-19 \mathrm{~cm})$ is reddish brown $(2.5 \mathrm{YR} 5 / 4)$, loose, porous and lumpy with abundant roots. The transition with the underlying $A B$ horizon is diffuse. The $\mathrm{AB}$ horizon (19-44 cm) is reddish brown (5YR4/6), lumpy, and lightly compact. It shows few roots and its transition with the underlying Bw horizon is sharp. The Bw horizon $(44-86 \mathrm{~cm})$ is sub-angular polyhedric, a moderately compact, lightly porous and roots are absent. $\mathrm{Cr}$ is more than $86 \mathrm{~cm}$ thick. It corresponds to a Eutric Cambisols (Ochric) soil class.

The bulk density (Da) (1.02 to $1.22 \mathrm{~g} / \mathrm{cm}^{3}$ ) and the particle density (Dr) (2.40 to $2.66 \mathrm{~g} / \mathrm{cm}^{3}$ ) in all topographic segments don't stray too far from each other (Table 2). This can be explained by the fact that these soils belong to the same reference group of soils (Cambisol) for profiles P2 to P4. For the P1 profile (Da: 1.45 to $1.74 \mathrm{~g} / \mathrm{cm}^{3}$; Dr: 2.40 to $2.45 \mathrm{~g} / \mathrm{cm}^{3}$ ). These soils are dense due to their high sand content. For the values of the total porosity, a slight deviation from the values for the surface horizons, from the top of slope of the others is noticed. This can be explained by the difference between textural classes. There are no coarse surface features in all topographic segments. This favors manual work in the study area. The slaking index carried out in the study area varies from 0.19 to 1.28 , which shows that these soils are non-slaking because they are all less than 1.4 on the one hand. The structural stability index ranges from 2.71 to 21.55 on the other hand. Most of the surface horizons have a structural stability index greater than 9 except the A horizon (5.94) of P4. For some, they have degraded structures (greater than 9) and for others the risks of structural degradation are low (less than 9).

\subsection{Chemical Characteristics and Fertility Index}

At the top and bottom of the slope, the soils are moderately acidic from the surface to the subsurface horizons and the $\mathrm{pHH}_{2} \mathrm{O}$ decreases from the surface to subsurface (Table 2). At mid-slope, it is the same from the surface to the depth horizons, the soil is slightly acidic. These $\mathrm{pH}$ values are normally suitable for most crops in tropical environments. At the foot of the slope the $\mathrm{pH}$-water is very low $(<5)$. A higher soil organic matter content was observed at the surface (less than $40 \mathrm{~cm}$ ) than at depth except the A horizon of P4. This character was observed both at the summit, middle and footslope positions (Table 2). 
Table 2. Soil physical and chemical properties.

\begin{tabular}{|c|c|c|c|c|c|c|c|c|c|c|c|c|c|c|}
\hline \multirow{2}{*}{\multicolumn{3}{|c|}{ soil characteristics }} & \multicolumn{2}{|c|}{ P1 } & \multicolumn{4}{|c|}{ P2 } & \multicolumn{3}{|c|}{ P3 } & \multicolumn{3}{|c|}{ P4 } \\
\hline & & & $\begin{array}{c}\mathrm{Ag} \\
(0-10 \\
\mathrm{cm})\end{array}$ & $\begin{array}{c}\mathrm{Bg} \\
(10-127 \\
\mathrm{cm})\end{array}$ & $\begin{array}{c}\text { A1 } \\
(0-10 \\
\mathrm{cm})\end{array}$ & $\begin{array}{c}\text { BA } \\
(10-40 \\
\mathrm{cm})\end{array}$ & $\begin{array}{c}\text { Bw1 } \\
(40-70)\end{array}$ & $\begin{array}{c}\text { Bw2 } \\
(70-120 \\
\mathrm{cm})\end{array}$ & $\begin{array}{c}\mathrm{A} 1 \\
(0-25 \\
\mathrm{cm})\end{array}$ & $\begin{array}{c}\text { BA } \\
(25-40 \\
\mathrm{cm})\end{array}$ & $\begin{array}{c}\text { B4 } \\
(40-105 \\
\mathrm{cm})\end{array}$ & $\begin{array}{c}\text { A1 } \\
(0-19 \\
\mathrm{cm})\end{array}$ & $\begin{array}{c}\mathrm{AB} \\
(19-44 \\
\mathrm{cm})\end{array}$ & $\begin{array}{c}\mathrm{Bw} \\
(44-86 \\
\mathrm{cm})\end{array}$ \\
\hline \multirow{2}{*}{ Sand } & \multicolumn{2}{|c|}{ Fine sand } & 27 & 11 & 60 & 50 & 60 & 50 & 60 & 60 & 60 & 50 & 50 & 50 \\
\hline & \multicolumn{2}{|c|}{ Coarse sand } & 23 & 18 & 7 & 10 & 8 & 10 & 13 & 8 & 5 & 10 & 10 & 14 \\
\hline \multirow{2}{*}{ Slit } & \multicolumn{2}{|c|}{ Fine silt } & 9 & 11 & 20 & 20 & 20 & 20 & 20 & 20 & 20 & 6 & 20 & 20 \\
\hline & \multicolumn{2}{|c|}{ Coarse silt } & 10 & 13 & 3 & 6 & 2 & 10 & 4 & 8 & 3 & 2 & 3 & 3 \\
\hline \multicolumn{3}{|c|}{ Clay } & 31 & 47 & 17 & 14 & 10 & 10 & 3 & 5 & 12 & 32 & 30 & 13 \\
\hline \multicolumn{3}{|c|}{ Texture } & $\begin{array}{l}\text { Sandy } \\
\text { clay } \\
\text { loam }\end{array}$ & clay & $\begin{array}{l}\text { Fine } \\
\text { sandy } \\
\text { loam }\end{array}$ & $\begin{array}{l}\text { Fine } \\
\text { sandy } \\
\text { loam }\end{array}$ & $\begin{array}{l}\text { Fine } \\
\text { sandy } \\
\text { loam }\end{array}$ & $\begin{array}{l}\text { Fine } \\
\text { sandy } \\
\text { loam }\end{array}$ & $\begin{array}{l}\text { Fine } \\
\text { sandy } \\
\text { loam }\end{array}$ & $\begin{array}{l}\text { Fine } \\
\text { sandy } \\
\text { loam }\end{array}$ & $\begin{array}{l}\text { Fine } \\
\text { sandy } \\
\text { loam }\end{array}$ & $\begin{array}{l}\text { Sandy } \\
\text { clay } \\
\text { loam }\end{array}$ & $\begin{array}{l}\text { Sandy } \\
\text { clay } \\
\text { loam }\end{array}$ & $\begin{array}{l}\text { Fine } \\
\text { sandy } \\
\text { loam }\end{array}$ \\
\hline \multicolumn{3}{|c|}{ Particle density $\left(\mathrm{g} / \mathrm{cm}^{3}\right)$} & 2.45 & 2.40 & 2.64 & 2.62 & 2.60 & 2.61 & 2.64 & 2.62 & 2.6 & 2.64 & 2.66 & 2.63 \\
\hline \multicolumn{3}{|c|}{ Bulk density $\left(\mathrm{g} / \mathrm{cm}^{3}\right)$} & 1.45 & 1.74 & 1.1 & 1.07 & 1.22 & 1.06 & 1.07 & 1.03 & 1.22 & 1.12 & 1.04 & 1.02 \\
\hline \multicolumn{3}{|c|}{ Moisture content } & 48.2 & 60.27 & 25.12 & 31.40 & 37.10 & 35.15 & 40.25 & 38.40 & 38.40 & 40.15 & 37.48 & 32.45 \\
\hline \multicolumn{3}{|c|}{ Porosity (\%) } & 40.08 & 27.50 & 41.67 & 39.46 & 41.67 & 40.77 & 40.68 & 39.46 & 41.67 & 42.42 & 39.1 & 38.78 \\
\hline \multicolumn{3}{|c|}{ Structuralist index } & 21.55 & 9.11 & 11.55 & 10.60 & 2.53 & 1.98 & 15.13 & 12.68 & 10.51 & 5.94 & 3.98 & 2.71 \\
\hline \multicolumn{3}{|c|}{ Slaking index } & 1.19 & 0.24 & 0.29 & 0.47 & 0.66 & 0.67 & 0.21 & 0.23 & 0.44 & 1.04 & 1.28 & 0.72 \\
\hline \multirow{4}{*}{\multicolumn{2}{|c|}{$\begin{array}{c}\text { Exchangeable bases } \\
\text { (cmol/kg de soil) }\end{array}$}} & $\mathrm{Ca}$ & 1.15 & 0.87 & 2.96 & 1.84 & 1.24 & 1.18 & 3.20 & 2.96 & 0.32 & 0.02 & 0.64 & 0.64 \\
\hline & & $\mathrm{Mg}$ & 0.8 & 0.41 & 0.06 & 0.04 & 0.06 & 0.02 & 0.06 & 0.03 & 0.04 & 0.04 & 0.02 & 0.02 \\
\hline & & $\mathrm{K}$ & 0.45 & 0.25 & 0.24 & 0.76 & 0.56 & 0.92 & 2.00 & 0.64 & 0.08 & 0.08 & 0.16 & 0.56 \\
\hline & & $\mathrm{Na}$ & 0.01 & 0.02 & 0.06 & 0.05 & 0.04 & 0.02 & 0.04 & 0.03 & 0.03 & 0.03 & 0.02 & 0.01 \\
\hline \multicolumn{3}{|c|}{$\begin{array}{l}\text { Sum of exchangeable } \\
\text { bases }(\mathrm{cmol} / \mathrm{kg})\end{array}$} & 2.51 & 1.55 & 3.32 & 2.69 & 1.91 & 2.14 & 5.30 & 3.66 & 0.47 & 1.23 & 1.23 & 1.23 \\
\hline \multicolumn{3}{|c|}{$\begin{array}{c}\text { CEC pH7 } \\
\text { (cmolc/kg of soil) }\end{array}$} & 17.5 & 15.5 & 7.6 & 6.54 & 4.64 & 4.52 & 8.23 & 8.17 & 7.88 & 6.52 & 5.68 & 5.06 \\
\hline \multicolumn{3}{|c|}{ Bases saturation $\%$} & 14.34 & 9.87 & 43.68 & 41.13 & 41.16 & 47.34 & 64.4 & 44.8 & 5.96 & 18.87 & 21.65 & 24.31 \\
\hline \multicolumn{3}{|c|}{ Available P (mg/kg) } & 13 & 11 & 7.98 & 2.52 & 4.5 & 1 & 2.13 & 0.82 & 2.72 & 7.98 & 2.52 & 4.5 \\
\hline \multicolumn{3}{|c|}{$\begin{array}{l}\text { Exchangeable Al } \\
\left(\mathrm{cmolc}+\mathrm{kg}^{-1}\right)\end{array}$} & 2.2 & 2.4 & 0 & 0 & 0 & 0 & 0 & 0 & & 0.7 & 0.7 & 0.8 \\
\hline \multicolumn{3}{|c|}{ Al toxicity (\%) } & 46.71 & 60.76 & 0 & 0 & 0 & 0 & 0 & 0 & & 36.27 & 36.27 & 39.41 \\
\hline \multicolumn{3}{|c|}{$\begin{array}{l}\text { Electrical conductivity } \\
\text { (CE) }(\mathrm{mS} / \mathrm{cm})\end{array}$} & 0.02 & 0.01 & 0.03 & 0.02 & 0.04 & 0.03 & 0.01 & 0.02 & 0.04 & 0.03 & 0.02 & 0.01 \\
\hline Exchang & eable sodiu & $\mathrm{n} \%$ & 0.06 & 0.13 & 0.79 & 0.76 & 1.29 & 1.11 & 0.49 & 0.37 & 0.38 & 0.15 & 0.18 & 0.2 \\
\hline & $\mathrm{pH}_{\mathrm{H} 20}$ & & 4.5 & 4.1 & 5.9 & 5.8 & 5.7 & 5.7 & 6.9 & 6.8 & 6.5 & 5.8 & 5.7 & 5.5 \\
\hline & $\mathrm{pH}_{\mathrm{KCl}}$ & & 3.8 & 3.5 & 4.6 & 4.4 & 4.4 & 4.4 & 5.6 & 5.5 & 4.9 & 5.1 & 4.9 & 4,8 \\
\hline Organi & c Carbon ( & & 6.25 & 3.75 & 2.21 & 1.84 & 0.47 & 0.55 & 2.50 & 1.92 & 1.12 & 0.41 & 1.18 & 0.11 \\
\hline & NT (\%) & & 0.32 & 0.22 & 0.12 & 0.12 & 0.11 & 0.09 & 0.17 & 0.15 & 0.11 & 0.12 & 0.07 & 0.06 \\
\hline
\end{tabular}

The abundance of organic matter on the surface is favorable for crop cultivation and gives the soils a good capacity to retain the nutrients provided during fertilization. These soils are poorly supplied with available nitrogen (mineral) 
(Table 2). Apart from the surface A horizon at the shoulder slope, where the sum of exchangeable bases is medium $\left(5.30 \mathrm{cmol} \cdot \mathrm{kg}^{-1}\right)$, the sum of exchangeable bases is very low to low (Table 2) for all the other horizons of the topographic segments $\left(1.23 \mathrm{cmol} \cdot \mathrm{kg}^{-1}\right.$ to $\left.3.66 \mathrm{cmol} \cdot \mathrm{kg}^{-1}\right)$ for depths $0-40 \mathrm{~cm}$. The concentrations of $\mathrm{Ca}$ and $\mathrm{Na}$ decrease with depth. $\mathrm{Mg}$ concentrations are constant in the P4 horizons of the summit soils, decreases with depth at footslope and evolve irregularly in the last two topographic segments. Like magnesium, the potassium concentration is also constant at the hill summit, it decreases when the depth increases at shoulder and footslope and finally it evolves in a saw-teeth in the last topography segment. The CEC varies $\left(6.52\right.$ to $\left.5.06 \mathrm{cmol} \cdot \mathrm{kg}^{-1}\right)$ in the horizons of the surface at depth at summit. At shoulder, it varies $\left(8.23\right.$ to $\left.7.88 \mathrm{cmol} \cdot \mathrm{kg}^{-1}\right)$ from surface to depth. The base saturation, except for the surface A horizon of the shoulder, is moderate, while that of the other horizons is very weakly to weakly saturated with exchangeable bases. The available phosphorus content is very low in all topographic segments and it varies from 0.82 to $13 \mathrm{mg} / \mathrm{kg}$. The aluminum toxicity varies from $36.27 \%$ to $60.75 \%$ but it is zero in the shoulder and backslope profiles, increases with depth in the footslope and summit. Concerning the fertility indices, the silt/clay ratio varies from 0.25 to 10.50 . This ratio is low in profiles $\mathrm{P} 1$ and $\mathrm{P} 4$ because it is less than 1, it is high in profiles backslope and shoulder because this ratio is greater than 1 (Table 3 ). The $\mathrm{C} / \mathrm{N}$ ratio varies from 1.93 to $29.06 ; \mathrm{TN} / \mathrm{pH}$ ranges from 0.01 to $0.07 ; \mathrm{N} / \mathrm{P}$ ranges from 0.02 to 0.26 and $\mathrm{C} / \mathrm{P}$ ranges from 0.10 to 2.34 . Most of the ratios evolve in a saw-teeth pattern in the horizons of all profiles, except the silt/clay and $\mathrm{C} / \mathrm{N}$ ratios at footslope and backslope where they decrease with depth of profile (Table 3). The equilibrium ratio $\mathrm{Ca}^{2+} / \mathrm{Mg}^{2+}$ ranges from 52.00 to 32.00 and decreases from the surface horizon to the sub-surface horizon and becomes constant at the summit of the hill. From shoulder to footslope, this relationship is changing in a roller coaster ride. The $\mathrm{Mg} / \mathrm{K}$ ratio oscillates between 0.02 and 1.78 for all horizons of the topographic segments and less than 3 (Table 3 ). The $\mathrm{Ca} / \mathrm{Mg} / \mathrm{K}$ ratio shows that the concentration of exchangeable potassium is high in the profiles along the slope and varies from 0.45 to $2 \mathrm{cmol} \cdot \mathrm{kg}^{-1}$. The Forestier's index (F) ranges from 0.04 to 1.34. The fertility index (FI) ranges from 51.37 (Bw at summit) to 91.34 (A at footslope) and is above 50 in all horizons. The carbon stock (SOCS) varies from $2.15 \mathrm{tC} / \mathrm{ha}(\mathrm{P} 4)$ to $1837.5 \mathrm{tC} / \mathrm{ha}(\mathrm{P} 1)$. It decreases with altitude (Table 3).

\section{Discussion}

The studied soils are brown and well aerated, except the P1 at footslope where they are dark grey. Most of the soil profiles (P2, P3 and P4) are characterized by high sand contents. This is probably due to the nature of the granitic bedrock, whose extensive weathering results in the release of grains of sand and the downslope movement of fine-grained particles under the influence of gravity (Adéchina et al., 2018). The clay content is therefore very low in all topographic segments except the first two horizons (A and $\mathrm{AB}$ ) of P4 and P1. These low clay 
Table 3. Nutrient ratios and fertility indices of the Dschang mountainous soils.

\begin{tabular}{|c|c|c|c|c|c|c|c|c|c|c|c|c|c|}
\hline $\begin{array}{l}\text { Ratio and } \\
\text { Indices }\end{array}$ & $\begin{array}{l}\text { Slit/Clay } \\
\text { ratio }\end{array}$ & $\mathrm{C} / \mathrm{N}$ & $\mathrm{TN} / \mathrm{PH}$ & $\mathrm{N} / \mathrm{P}$ & $\mathrm{C} / \mathrm{P}$ & $\mathrm{Mg} / \mathrm{K}$ & $\mathrm{Ca} / \mathrm{Mg}$ & $\begin{array}{c}\text { Bases } \\
\text { saturation\% }\end{array}$ & $\mathrm{Ca} / \mathrm{Mg} / \mathrm{K}$ & CRC & F & FI & $\begin{array}{l}\text { socs } \\
(\mathrm{tC} / \mathrm{ha})\end{array}$ \\
\hline \multicolumn{14}{|c|}{$\mathrm{P} 1$} \\
\hline$A(0-10 \mathrm{~cm})$ & 0.61 & 19.53 & 0.02 & 281.03 & 4805.46 & 1.78 & 1.56 & 14.34 & $50 / 32 / 18$ & $0.66 / 1.78 / 2.67$ & 0.16 & 91.34 & \multirow[b]{2}{*}{1837.50} \\
\hline $\begin{array}{c}\text { B } \\
(10-127 \mathrm{~cm})\end{array}$ & 0.49 & 17.05 & 0.01 & 171.99 & 3125.00 & 1.64 & 2.12 & 9.87 & $57 / 27 / 16$ & $0.75 / 1.5 / 2.67$ & 0.04 & 87.79 & \\
\hline \multicolumn{14}{|c|}{ P2 } \\
\hline$A(0-10 \mathrm{~cm})$ & 2.14 & 18.5 & 0.01 & 2608.70 & 2769.39 & 0.25 & 49.30 & 43.68 & $91 / 2 / 7$ & $1,20 / 0,11 / 1,17$ & 0.48 & 71.50 & \multirow{4}{*}{42.55} \\
\hline $\begin{array}{c}\text { BA } \\
(10-40 \mathrm{~cm})\end{array}$ & 6.5 & 15.94 & 0.02 & 798.12 & 7319.63 & 0.05 & 46.00 & 41.13 & $70 / 2 / 29$ & $0.92 / 0.11 / 4.83$ & 0.38 & 62.76 & \\
\hline $\begin{array}{c}\text { B41 } \\
(40-70 \mathrm{~cm})\end{array}$ & 2.37 & 4.24 & 0.02 & 1829.27 & 1044.08 & 0.11 & 20.66 & 41.16 & $67 / 3 / 30$ & $0.88 / 0.17 / 5.00$ & 0.17 & 65.81 & \\
\hline $\begin{array}{c}\text { B42 } \\
(70-120 \mathrm{~cm})\end{array}$ & 1.07 & 5.81 & 0.02 & 404.41 & 5452.44 & 0.02 & 59.00 & 47.34 & $56 / 1 / 43$ & $0.74 / 0.55 / 7.2$ & 0.13 & 56.06 & \\
\hline \multicolumn{14}{|c|}{ P3 } \\
\hline$A(0-25 \mathrm{~cm})$ & 10.5 & 14.9 & 0.02 & 150.38 & $11,737.09$ & 0.03 & 53.30 & 64.40 & $61 / 1 / 38$ & $0.80 / 0.06 / 6.33$ & 1.34 & 68.79 & \multirow{3}{*}{21.02} \\
\hline $\begin{array}{c}\text { BA } \\
(25-40 \mathrm{~cm})\end{array}$ & 2.24 & 13.02 & 0.02 & 476.19 & $23,414.07$ & 0.05 & 98.70 & 44.80 & $82 / 1 / 18$ & $1.08 / 0.06 / 3.00$ & 0.56 & 63.40 & \\
\hline $\begin{array}{c}\text { B4 } \\
(40-105 \mathrm{~cm})\end{array}$ & 6.88 & 9.99 & 0.02 & 244.44 & 4115.77 & 0.50 & 8.00 & 5.96 & $73 / 1 / 18$ & $0.96 / 0.06 / 3.00$ & 0.01 & 62.38 & \\
\hline \multicolumn{14}{|c|}{$\mathrm{P} 4$} \\
\hline$A(0-19 \mathrm{~cm})$ & 0.33 & 3.33 & 0.02 & 281.03 & 950.90 & 0.13 & 52.00 & 18.87 & $85 / 2 / 13$ & $1.12 / 0.11 / 2.17$ & 0.07 & 62.88 & \multirow{3}{*}{2.15} \\
\hline BA $(19-40)$ & 0.25 & 29.06 & 0.01 & 171.99 & 2893.11 & 0.04 & 32.00 & 21.65 & $52 / 2 / 46$ & $0.68 / 0.11 / 7.67$ & 0.04 & 59.62 & \\
\hline $\begin{array}{c}\text { B4 } \\
(40-86 \mathrm{~cm})\end{array}$ & 0.77 & 1.93 & 0.01 & 2608.70 & 4791.69 & 0.04 & 32.00 & 24.31 & $52 / 2 / 46$ & $0.68 / 0.11 / 7.67$ & 0.10 & 52.87 & \\
\hline
\end{tabular}

*: most concentrated element that determines the direction of equilibrium; CRC: coefficient of relative concentration; ${ }^{*}$ most concentrated element that determines the direction of equilibrium; CRC: coefficient of relative concentration; F: Forestier's Index (Sum of bases) ${ }^{2} /($ Clay + fine silt); FI: fertility index; SOCS: soil organic carbon stocks.

content values have consequences on the quality of the soils, in particular their chemical fertility. The structure of soils in all surface horizons is lumpy. The lumpy structure is ideal for agriculture. The bulk density values of P2, P3 and P4 do not differ very much from each other in agreement with the conclusions of (Nsanzimfura, 2015). At the surface and at depth, the total porosity is low and average values of bulk density imply that the voids are not reduced and the particles are not strongly compacted. Consequently, this will not result in difficulties in the circulation of water and air, as well as difficulties in root growth and seedling emergence. These results disagree with those of (Mermound, 2010) in that the soils in the study area have not yet been exploited. The silt/Clay ratio, greater than 0.15 , portrays relatively young soils with low degree of weathering. This agrees with the works of (Azinwi et al., 2018) whereby steep slope plays a vital role in rejuvenating soils. The results of the chemical analysis of the soils showed that the $\mathrm{pHH}_{2} \mathrm{O}$ of the studied soils is moderately to slightly acidic except that of $\mathrm{P} 1$ which is very acidic. This soil $\mathrm{pH}$ is favorable for growth of most plants unlike P1 which only admits plants that tolerate acidity according to 
(Beernaert \& Bitondo, 1992). The soils are characterized by a low to high organic matter content, low total nitrogen and low sum of exchangeable cations as is commonly documented in steep slope soils of tropical landscapes (Dabin, 1964). The available phosphorus in all soils is low according to (Euroconsult, 1989; Beernaert \& Bitondo, 1991), and might be probably fixed by free aluminum and iron. In addition, the $\mathrm{C} / \mathrm{N}$ ratio of the soils is high and is possibly interpreted as being of low quality and depicts slow mineralization of the organic matter, unlike that of $\mathrm{P} 4$ (3.33) which is low. The NT/pH ratio $(\leq 0.01$ and $0.01<0.08)$ in soils is low and decreases with depth. The high N/P ratio $(>100)$ shows the unavailability of available phosphorus in soils and confirmed by the $\mathrm{C} / \mathrm{P}$ ratio which is also high (Forestier, 1960). A part from the $\mathrm{P} 1$ at footslope, the $\mathrm{Mg} / \mathrm{K}$ ratio shows a risk of $\mathrm{Mg}$ deficiency in the other profiles. The $\mathrm{Ca} / \mathrm{Mg}$ ratio is high (>6) for the P2, P3 and P4 profiles confirming a potential magnesium deficiency (Beernaert \& Bitondo, 1991). The low $\mathrm{Ca} / \mathrm{Mg}$ ratio in $\mathrm{P} 1(<2.56)$ depicts a potential Ca and Mg deficiency (Beernaert \& Bitondo, 1991). The $\mathrm{Ca} / \mathrm{Mg} / \mathrm{K}$ balance in all profiles shows a relatively a cationic imbalance of the three cations and a relatively high concentration of exchangeable potassium. Compared to the ideal (76\% Ca, 18\% Mg and 6\% K) according to (Beernaert \& Bitondo, 1991). The exchangeable calcium is in deficient in all the profiles in the first $25 \mathrm{~cm}$ depth. For this reason, $741 \mathrm{tCaO} /$ ha will be required by $\mathrm{P} 1,3.55 \mathrm{tCaO} /$ ha (plus 0.83 $\mathrm{tMgO} / \mathrm{ha}$ ) by $\mathrm{P} 2,16.57 \mathrm{tCaO} / \mathrm{ha}$ (plus $3.16 \mathrm{tMgO} / \mathrm{ha}$ ) by $\mathrm{P} 3$ and $0.02 \mathrm{t} \mathrm{MgO} / \mathrm{ha}$ by $\mathrm{P} 4$ to raise the base saturation rate to optimum at a depth of $25 \mathrm{~cm}$ at a rate of $76 \% \mathrm{Ca}, 18 \% \mathrm{Mg}$ and $6 \% \mathrm{~K}$ (Figure 3 ). The Forestier's index is low $(\mathrm{F}<1)$ in all surface horizons $(0-25 \mathrm{~cm})$ in profiles $\mathrm{P} 1, \mathrm{P} 2$ and $\mathrm{P} 4$ and corresponds to scale 3 which results in poor fertility except for the A horizon of P3 $(1<\mathrm{F}<2)$ of scale4 (moderate fertility) (Bindzi, 1987). The fertility index (FI) indicates that all the soils are in the range lightly fertile soils except for $\mathrm{P} 1$ which are moderately fertile. Soil organic carbon stocks (SOCS) decreases with increasing altitude joins the work of (Azinwi et al., 2020).

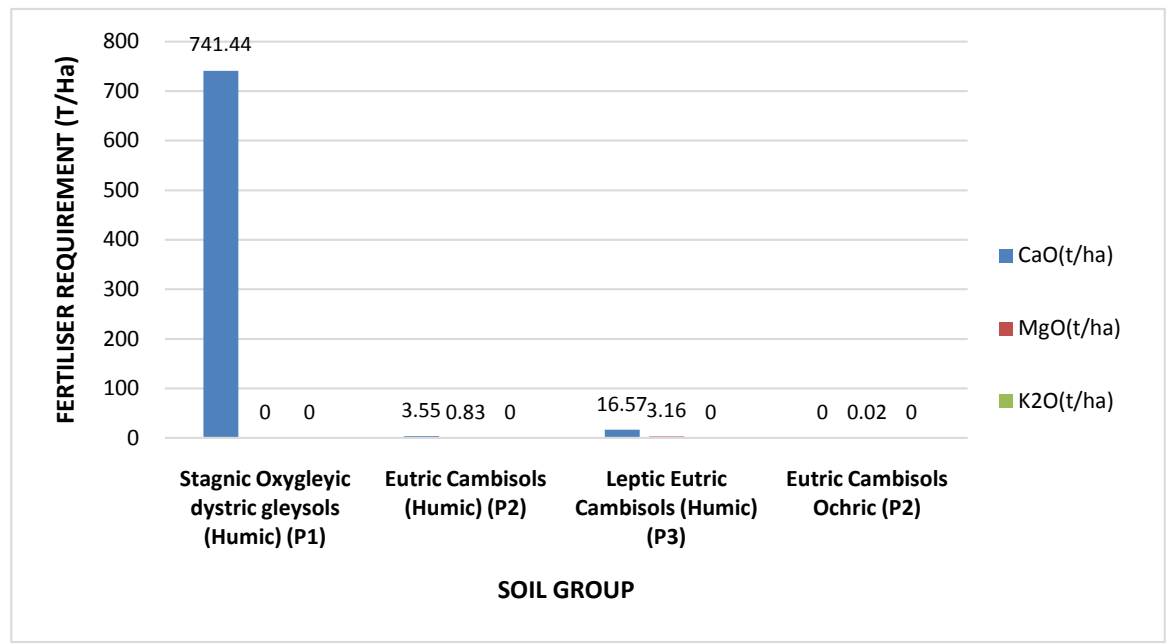

Figure 3. Recommended fertilizer doses required to raise soil base saturation to optimium for the $25 \mathrm{~cm}$ depth with a $\mathrm{Ca} / \mathrm{Mg} / \mathrm{K}$ rate of $76 / 18 / 6$ for the different soils. 
Soil fertility capability classification is often used to deduce soil constraints that limit crop production. In the present study, the major constraints for production are: aluminum toxicity (a) and leaching of nutrients (e) in all profiles, the low nutrient reserve (k) for profiles P1, P2 and P4, steep slope for P2 and P3 is one of them. Also, there is a textural discontinuity (LS) within the first 25 cmof the P4 and flooding (g) in the P1 profile. The FCC includes CCaegk (P1), SStek (P2), SSte (P3) and LSaek (P4) (Table 4). These results corroborate those found by (Tabi et al., 2013; Azinwi et al., 2018).

The evaluation of land for common crops like maize, groundnuts, cocoa and Arabica coffee show a high suitability of humidity without any limitations in P2, P3 and P4 meanwhile P1 shows very marginal humidity with the severe limitations. The texture exhibits high suitability with low limitations in all profiles for maize and groundnut crops; it presents an average suitability with average limitations in P1, P2 and P3 for the cocoa and Arabica coffee. The CEC shows low limitations for all crops in P1 and moderate limitations for crops in P2, P3 and P4 (groundnuts); it shows severe limitations in P4 for maize, cocoa and coffee. The base saturation shows low limitations for all crops in P2 and P3, and moderate limitation for groundnuts in P1 and P4 as well as coffee in P1. Likewise, base saturation presents very severe limitations for maize and cocoa in P1 and unsuitable but correctable limitation for coffee in $\mathrm{P} 4 . \mathrm{PH}_{\mathrm{H} 2 \mathrm{O}}$ has very severe limitations for groundnuts, coffee and cocoa and is unsuitable for maize in P1. $\mathrm{PH}_{\mathrm{H} 2 \mathrm{O}}$ has low limitations for corn, peanuts and cocoa in P3 and P2. Salinity and contents of coarse fragments show no limitation in all profiles for all crops. The profile depth shows very severe limitation and is unfit for cocoa cultivation, and a severe limitation for Arabica coffee in P4. These two parameters reveal a moderate

Table 4. Soil fertility limitations and fertility capability classification (FCC) units.

\begin{tabular}{|c|c|c|c|c|c|}
\hline Categoricals levels & & P1 & P2 & P3 & $\mathrm{P} 4$ \\
\hline Type & & $\mathrm{C}$ & S & $S$ & $\mathrm{~L}$ \\
\hline Substrat type & & $\mathrm{C}$ & S & S & S \\
\hline \multirow{8}{*}{ Modifier s } & $\mathrm{t}$ & - & + & + & - \\
\hline & a & + & + & - & + \\
\hline & $\mathrm{b}$ & - & - & - & - \\
\hline & $\mathrm{e}$ & - & + & + & + \\
\hline & g & + & - & - & - \\
\hline & $\mathrm{k}$ & + & + & - & + \\
\hline & $\mathrm{m}$ & - & - & - & - \\
\hline & $\mathrm{v}$ & - & - & - & - \\
\hline FCC & & CCaegk & SStek & SSte & LSaek \\
\hline
\end{tabular}

C: clayed textured; t: slope; a: aluminium toxicity; b: basic reaction; e: high leaching potential; g: water logging; k: low nutrient capital reserve; m: organic matter depletion; S: sandy textured, L: Loamy textured v: vertic properties; +: greater expression of the modifier; -: lesser expression of the modifier. 
limitation for coffee and cocoa in P3 and P4, and low limitations for maize and groundnuts in $\mathrm{P} 4$ and $\mathrm{P} 1$. The climate presents a marginal suitability for maize and groundnuts with severe limitations due to annual precipitation. This is the same suitability class for growing coffee in P2, P3 and P4. The precipitation shows suitability for coffee and slight limitations in P1 (Table 5).

Table 5. Soil suitability for the cultivation of maize, groundnuts, Arabica coffee and cocoa by simple parametric method.

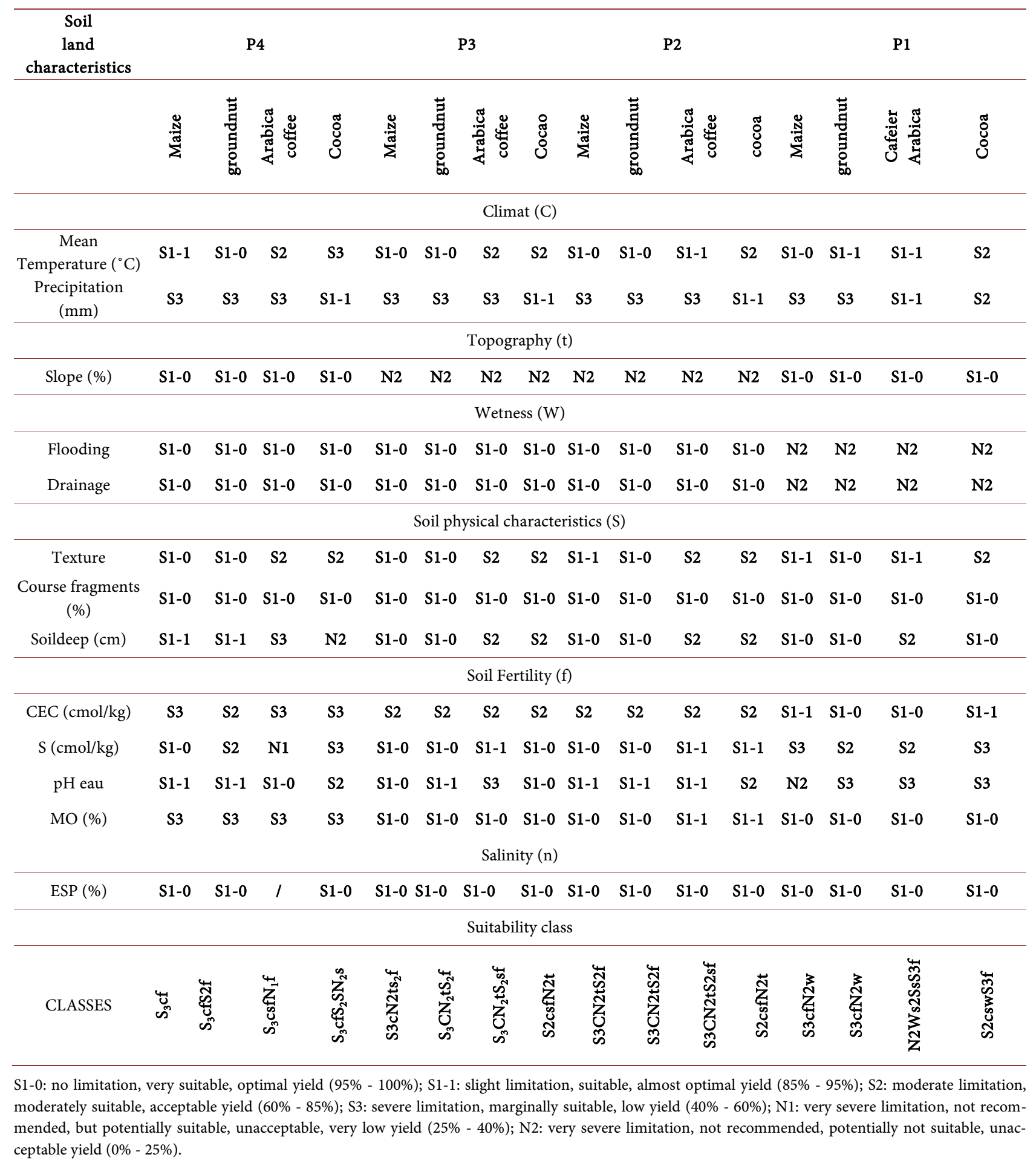




\section{Conclusion and Recommandations}

The agricultural exploitation of land on the Dschang hills (Cameroon Western Highlands) requires a mastery of the soil properties in this mountainous ecosystem. Therefore, this work was conducted to characterize the steep slopes soils of the Dschang hills and to evaluate their fertility level for agricultural valorization. Thus four types of soils are represented in this area, namely Eutric Cambisols (ochric) in the summit, Leptic Eutric Cambisols (Humic) at the shoulder slope, Eutric Cambisols (Humic) at the backslope and Stagnic Oxygleyic dystric gleysols (Humic) at the footslope. Sand is the dominant particle size fraction (more than 50\%) in all the profiles. The soil structure is lumpy, stable in the lower and upper slope sand thus suitable for agriculture. Chemical analysis revealed that the soils are very acidic to weakly acidic with organic matter higher at the surface than at depth. The cation exchange capacity, the sum of exchangeable bases, total nitrogen and available phosphorus are low in all profiles. The $\mathrm{Ca} / \mathrm{Mg} / \mathrm{K}$ ratio in the profiles is unbalanced with respect to the ideal situation $(76 \% \mathrm{Ca}, 18 \%$ $\mathrm{Mg}$ and $6 \% \mathrm{~K})$ and exchangeable potassium reveals the coefficient of relative concentration and thus determines the sense of equilibrium. The relative concentration of exchangeable calcium is low compared to the ideal situation in all the profiles. The major constraints of these soils to the growth of crops are aluminum toxicity (a) and nutrient leaching (e), textural discontinuity (LS), flooding $(\mathrm{g})$, low nutrient reserve $(\mathrm{k})$, sand $(\mathrm{S})$, clay $(\mathrm{C})$ and slope $(\mathrm{t})$. The fertility capability classes of these soils are: CCaegk at footslope, SStek at backslope, SSte at the shoulder and LSaek at the summit. To improve the yield, it will require offseason crops, fertilization, earthworks and liming.

\section{Acknowledgements}

The authors address special thanks to Dr. Georges Ndzana (Department of soil sciences University of Dschang Cameroon) for proofreading the article and to Mr. Cedric Nguemezi (Department of Earth sciences, University of Dschang, Cameroon) for drawing the soil profiles.

\section{Conflicts of Interest}

The authors declare no conflicts of interest regarding the publication of this paper.

\section{References}

Adéchina, O., Ouattara, A., \& N’Ganzoua, K. R. (2018). Caractéristiques morphologiques et physico-chimiques des sols savanicoles le long de toposéquences à Gogbala dans le Nord de la Côte d'Ivoire. International Journal of Innovation and Applied Studies, 25, 437-445.

Ancelin, O., \& Duranel, J. (2007). Mémento Sols et Matières Organiques-Agro-Transfert R\&T et Chambres d'Agriculture de Picardie.

Azinwi, Tamfuh, P., Chotangui, A. H., Katte, V. Y., Achantap, R. A., Magha, A. M. et al. (2020). Land Characteristics and Agricultural Suitability Status along a Toposequence 
in Santa, Bamenda Highlands, Cameroon. Journal of Atmospheric \& Earth Sciences, 4, 22. https://doi.org/10.24966/AES-8780/100022

Azinwi, Tamfuh, P., Temgoua, E., Wotchoko, P., Boukong, A., \& Bitom, D. (2018). Soil Properties and Land Capability Evaluation in a Mountainous Ecosystem of North-West Cameroon. Journal of Geoscience and Environment Protection, 6, 15-33. https://doi.org/10.4236/gep.2018.67002

Beernaert, F., \& Bitondo, D. (1991). Simple and Practical Methods to Evaluate Analytical Data of Soil Profiles. Belgian Cooperation/University of Dschang.

Beernaert, F., \& Bitondo, D. (1992). Land Evaluation Manual. Dschang University Centre. Bindzi, T. J. (1987). Les sols rouges du Cameroun. MEISRES-FAO.

Boyer, J. (1970). Summary of State-of-Knowledge on the Factors of Soil Fertility in French Intertropical Africa. ORSTOM.

Bucrep (2010) Fourth edition Bureau Central des Recensements et des Etudes de Population. Yaoundé Cameroun.

Climate-Data.org (2019). Climat-Dschang-Diagramme climatique, Courbe de température, Table climatique. https://fr.climate-data.org/afrique/cameroun/west/dschang-52924/

Dabin, B. (1964). General Study of Soil Usage Conditions in the Chad Trough. ORSTOM.

DSCE Document de Stratégie pour la Croissance et l'Emploi (2009). Cadre de référence de l'action gouvernementale pour la période 2010-2020.

Euroconsult (1989). Agricultural Compendium for Rural Development in the Tropics and the Subtropics. Elsevier.

FAO (2006). Food and Agriculture Organisation of the United Nations. Rome.

Forestier, J. (1960). Fertilité des Sols des Caféières en RCA. Agronome Tropical, 15, 543-567.

Fotsing, J. M. (1999). Croissance démographique et mise en culture des réserves forestières dans l'Ouest Cameroun. In R. E. Bilsborrow, \& D. Hogan (Eds.), Population and Deforestation in the Humid Tropics (pp. 76-98). International Union for Scientific Study of Population.

Griffon, M., \& Marty, I. (1993). Prospective des déséquilibres environnementaux liés à l'agriculture dans les pays tropicaux (288 p). CIRAD-GERDAT.

Mermound, A. (2010). Cours de physique du sol. Ouagadougou \& Lausane: 2iE \& Ecole polytechnique fédérale de lausane (p. 18).

Nsanzimfura, P. (2015). Master en ingenierie de l'eau et de l'environnement, option: Infrastructure et réseaux hydrauliques (IRH) (60 p).

Omoko, M. (1996). Éléments de pédologie appliqué cours $N^{\circ} D E 09$ SS. Enseignement à distance, Université de DSCHANG (160 p).

Pauwels, J. M., VanRanst, E., Verloo, M., \& Mvondo Ze, A. (1992). Manuel de Laboratoire de pedologie. Publications Agricoles No. 28. AGCD.

Sys, C., van Ranst, E., \& Debaveye, J. (1991). Land Evaluation. Part 1, Principles in Land Evaluation and Crop Production Calculation. Agricultural Publications No. 7, General Administration for Development Cooperation.

Tabi, F. O., Ngobesing, E. S. C., Yinda, G. S., Boukong, A., Omoko, M. et al. (2013). Soil Fertility Capability Classification (FCC) for Rice Production in Cameroon Lowlands. African Journal of Agricultural Research, 8, 1650-1660.

https://doi.org/10.5897/AJAR12.1576

WRB (World Reference base for soil Resources) (2014). International Soil Classification System for Naming Soils and Creating Legends for Soil Maps. FAO. 